\title{
Environmental Conditions, Phytochemical Constituents, and Antibacterial Activi- ties of Two Philippine Medicinal Vitaceae Species
}

\author{
Jeff M. Opeña ${ }^{* 1}$, Rachel C. Sotto ${ }^{2}$ \\ ${ }^{1}$ College of Agriculture, Cagayan State University-Gonzaga, Flourishing, Gonzaga, Cagayan, Philippines \\ ${ }^{2}$ Institute of Biological Sciences, College of Arts and Sciences, University of the Philippines Los Baños, College, \\ Los Baños, Laguna, Philippines
}

Article history:

Submission June 2021

Revised July 2021

Accepted August 2021

*Corresponding author:

E-mail: jmopena@csu.edu.ph

\begin{abstract}
Plants are utilized for medicinal, therapeutic, nutritional, and industrial importance. This study investigated the phytochemical constituents and antibacterial activities of two medicinal Vitaceae species, namely: Cayratia trifolia and Tetrastigma harmandii. The growing environment (location, elevation, soil properties, and associated plants) of the species in northeastern Cagayan, Luzon, Philippines, were assessed and leaf samples were collected for phytochemical screening and antibacterial analysis. T. harmandii dominated the population found growing in various habitats such as hills, residential areas, near coastal areas and island shorelines, nipa plantations, agricultural and grasslands, near bodies of water, caves, and secondary growth forests while $C$. trifolia were only found growing in swamps, hills, and secondary growth forests. Both plants were found climbing in plant species like ipil-ipil (Leucaena leucocephala) and kakawate (Gliciridia sepium). T. harmandii populations were growing in soils with lower soil $\mathrm{pH}$ and higher nutrient content as compared to $C$. trifolia populations which grew in soils with higher $\mathrm{pH}$ and lower nutrients. Antioxidant properties were exhibited by the presence of secondary metabolites. Alkaloids, flavonoids, phenols, terpenoids, anthocyanins, tannins, and saponins were detected in C. trifolia ethanolic leaf extracts while phenols, terpenoids, tannins, and saponins were detected in T. harmandii. Both species showed inhibitory activity against Staphylococcus aureus. In addition, a slight activity against Klebsiella aerogenes was observed for T. harmandii. Thus, C. trifolia and T. harmandii also have antibacterial properties.
\end{abstract}

Keywords: Antibacterial property, Cayratia trifolia (Linn.) Domin, Habitats and environment, Plant secondary metabolites, Staphylococcus aureus, Tetrastigma harmandii Planch

\section{Introduction}

Vitaceae species in the northern part of Luzon, Philippines, are diverse and some of these species are believed to be medicinal. Some of the Vitaceae species with medicinal properties are Cayratia trifolia (Linn.) Domin. and the common Tetrastigma species, Tetrastigma harmandii Planch (Figure 1). C. trifolia, locally known as kalit-kalit in the Philippines, is a herbaceous climber with trifoliolate leaves, ovate to oblong-ovate leaflets, and dark purple or black nearly spherical fruits [1] while $T$. harmandii, locally known as ayo or ariwat, is a woody vine with pedately compound leaves with 3(5)6 glossy dark green leaflets, simple tendrils, and rusty brown globose fruits [2]. Between the two Vitaceae species, only the Tetrastigma is parasitized by Rafflesia, which grows in the roots and stem of the said species [3]. The distribution of $C$. trifolia [4] and T. harmandii [2] in the Philippines and nearby countries was reported, however, their growing environments were the least explored.

$C$. trifolia and T. harmandii have been reported to possess various medicinal properties. $C$. trifolia was found to contain various phytochemicals such as steroids, flavonoids, tannins, carbohydrates [5], and stilbenes such as piceid, resveratrol, viviferin, ampelopsin [6]. Stilbenes in Cayratia

\section{How to cite:}

Opeña JM, Sotto RC (2022) Environmental conditions, phytochemical constituents, and antibacterial activities of two Philippine medicinal Vitaceae species. Journal of Tropical Life Science 12 (1): 11 - 19. doi: 10.11594/jtls.12.01.02. 


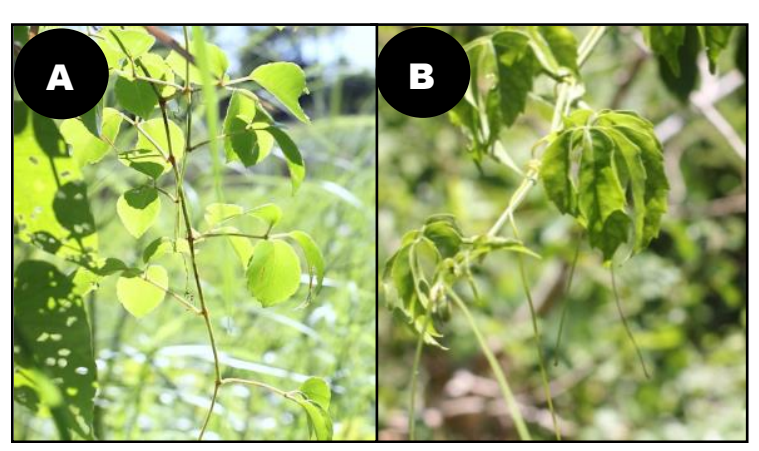

Figure 1. Medicinal Vitaceae species: Cayratia trifolia (A) and Tetrastigma harmandii (B)

were widely studied and were found to have various medical benefits. In terms of its pharmacological uses, the species was reported to have antioxidant activity [7], anti-ulcer property [8], hepatoprotective activity [9], anti-inflammatory activity [10], cardioprotective activities [11], antidiabetic properties [12, 13], antiviral effects [14], reduce vaginal and diseases, diarrhea, spleen disorders [15] and can treat scurvy [16]. On the other hand, T. harmandii was found to have anti-scabies and diuretic properties [17] and treat urinary diseases [16].

Despite the richness of knowledge on medicinal plants worldwide, a small number of scientific reports on C. trifolia and T. harmandii in the Philippines were reported. With the aforementioned health and medical benefits, this study compared the profiles of the two medicinal Vitaceae species commonly found growing in various habitats of the northeastern Cagayan, Luzon, Philippines in terms of their growing environment and their phytochemical and antibacterial properties.

\section{Material and Methods Sampling methods}

Study permits were secured from the Department of Environment and Natural Resources (DENR) Region 2 Office and various Local Government Units (LGUs) of northeastern Cagayan namely Lal-lo, Camalaniugan, Aparri, Buguey, Santa Teresita, Gonzaga, and Santa Ana. The municipalities were visited for the presence of $C$. trifolia and T. harmandii. The study encountered 2 accessions of $C$. trifolia and 36 accessions of $T$. harmandii. The accessions were planted in the Cagayan State University (CSU) -Gonzaga field gene bank and nursery. A combination of walk/vehicular ride, visual encounter, and photo documentation was employed from June to October 2020.
Geographical distribution and habitat conditions

The climatic condition during the experimental period is shown in Table 1. A geographical map for the medicinal Vitaceae species distribution in northeastern Cagayan was generated using the Google Earth Pro and the locations and elevations were determined using the Geocam Pro version 5.34 (Wazar-Apps, 6 Place Jacques Bonsergent, Paris, France). The various habitats where the two Vitaceae species grew and the plants growing within their environments were identified. The scientific, English and common/local names were provided.

Topsoil samples from various experimental sites where the species grew were gathered, pulverized, and subjected to air-drying at room temperature until total dryness. The soil $\mathrm{pH}$, organic carbon (OM), phosphorus, potassium, and trace elements (copper, zinc, iron, manganese) were tested through the Potentiometric method, Walkey and Black Spectrophotometric, Olsen's method, Cold Sulfuric Extraction, and diethylenetriaminepentaacetic acid (DTPA) extraction, respectively [18]. The rating scales guided the interpretation of soil test results for total $\mathrm{N}$, total $\mathrm{P}$, and total K [19], $\mathrm{pH}$, and micronutrients [18].

\section{Plant sample collection}

Fresh young and mature leaves of C. trifolia and T. harmandii were collected in Gonzaga, Lallo, and Santa Teresita, Cagayan. Their identities were verified through published photos of Vitaceae in Co's Digital Flora of the Philippines website [20].

\section{Analysis of phytochemical constituents and anti- microbial activity of the medicinal Vitaceae spe- cies}

\section{Preparation of the ethanolic leaf extracts}

The collected leaves were thoroughly washed with running tap water and rinsed with distilled water thrice. The leaves were air-dried at room temperature for 3-4 days, chopped into smaller pieces, oven-dried at $50^{\circ} \mathrm{C}$ for several hours, ground and pulverized using mortar and pestle then sieved to obtain a fine powder. The powder (200 g. $\mathrm{L}^{-1}$ ) was extracted using 90\% ethanol at room temperature, filtered using a filter paper, and collected the crude extracts.

\section{Phytochemical screening}

The leaf crude extracts were subjected to phy- 
Table 1. Climatic condition of northeastern Cagayan, Luzon, Philippines during the study

\begin{tabular}{|c|c|c|c|c|c|c|}
\hline \multirow{2}{*}{ Month (2020) } & \multicolumn{3}{|c|}{ Mean Temperature $\left({ }^{\circ} \mathrm{C}\right)$} & \multirow{2}{*}{$\begin{array}{l}\text { Mean Precipitation } \\
(\mathrm{mm})\end{array}$} & \multirow{2}{*}{$\begin{array}{c}\text { Mean Relative } \\
\text { humidity (\%) }\end{array}$} & \multirow{2}{*}{ Season } \\
\hline & Minimum & Average & Maximum & & & \\
\hline June & 26 & 30 & 32 & 273.9 & 79 & dry \\
\hline July & 26 & 29 & 31 & 224 & 80 & dry \\
\hline August & 25 & 29 & 30 & 237.5 & 81 & dry \\
\hline September & 26 & 29 & 31 & 241.1 & 81 & dry \\
\hline October & 25 & 27 & 28 & $1,014.70$ & 86 & wet \\
\hline
\end{tabular}

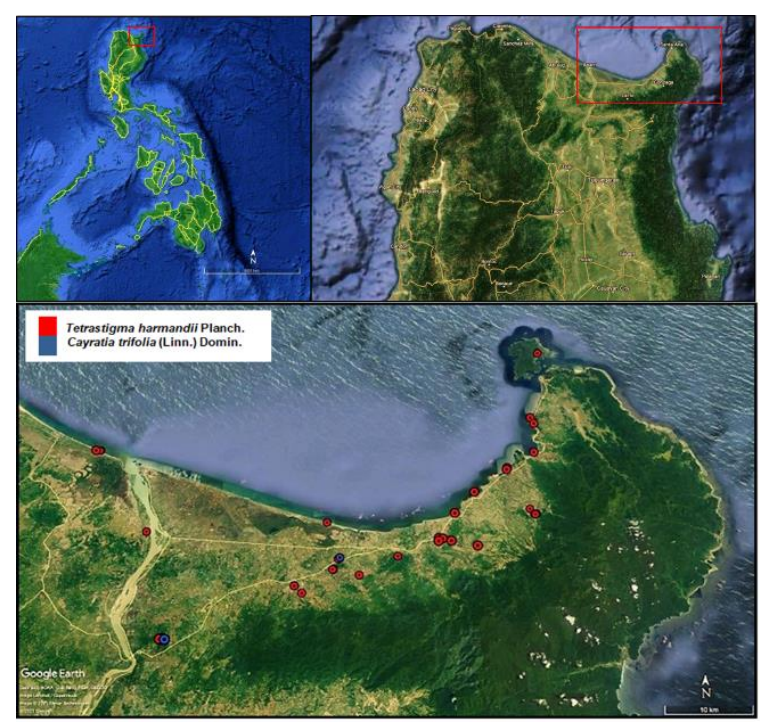

Figure 2. Geographical distribution of Cayratia trifolia (Linn.) Domin. and Tetrastigma harmandii Planch. in the northeastern part of Cagayan, Philippines.

tochemical screening to identify the presence of eight secondary metabolites. The tests used for the determination of alkaloids, anthocyanin, flavonoids, phenols, saponins, steroids, tannins, and terpenoids were Meyer's test, $\mathrm{NaOH}$ test, Shinoda test, Ferric Chloride test, Froth test, LiebermannBurchard reaction, Lead Acetate test, and Salkowski test, respectively [21].

\section{Determination of antibacterial activity}

The antibacterial properties of the plant crude extracts against gram-negative bacterial strains $E$. coli, $P$. aeruginosa, $K$. pneumoniae, $K$. aerogenes, and $A$. baumannii; and gram-positive bacteria $S$. aureus and $E$. faecium were tested using the paperdisc diffusion method [21]. Bacterial strains were from the Central Analytical Laboratory of CSUTuguegarao City, Cagayan, Philippines. The inoculum size of each test organism was standardized. The standardized inocula were then plated on Mueller-Hinton agar through cotton swabbing and the plates were incubated for 12 hours. Six sterilized paper discs (6-mm diameter) from Whatman No.1 filter paper were immersed in ethanolic leaf extracts and placed on inoculated Mueller-Hinton agar plates with the bacterial strains. The sample plates containing six paper discs were replicated thrice. The sample plates were then incubated at $37^{\circ} \mathrm{C}$ for 24 hours. Zones of inhibition were measured using a ruler and their corresponding interferences were described [21].

\section{Results and Discussions \\ Geographical distribution of medicinal Vitaceae species and their habitats}

C. trifolia populations in the northeastern Cagayan were few as compared to the populations of T. harmandii. C. trifolia were only found growing in Sta. Maria, Lal-lo and Luga, Santa Teresita, Cagayan while T. harmandii were distributed in all the municipalities of northeastern Cagayan (Figure 2). Both C. trifolia and T. harmandii grew in northeastern Cagayan environments with 25$32^{\circ} \mathrm{C}$ temperature, 224-1,014 mm rainfall, and 79$86 \%$ relative humidity (Table 1 ). It was observed that $T$. harmandii grew in lower elevations (34.14 meters above sea level (masl) lower) to higher altitudes (103.94 masl higher) as compared to C. trifolia. Both species grew in the lowland, near a swap, in hilly areas, and in secondary growth forests, however C. trifolia was found growing in flooded areas where the roots are fully submerged. Meanwhile, T. harmandii was found growing in other habitats such as residential areas, near coastal areas of Aparri, Buguey, Gonzaga, and Sta. Ana; in nipa plantations; various agricultural lands planted with vegetables, rice, and corn; grasslands/grazing areas; near bodies of water such as riverbanks, creeks, irrigation dam, and canals, and freshwater spring; outside the caves of Sta. Teresita and Lal-lo; and also near the seashores of Aparri, Buguey, Gonzaga, and Palaui Island Protected Landscape and Seascape in Sta. Ana, Cagayan (Figure 3, Table 2).

Both Cayratia and Tetrastigma species were 


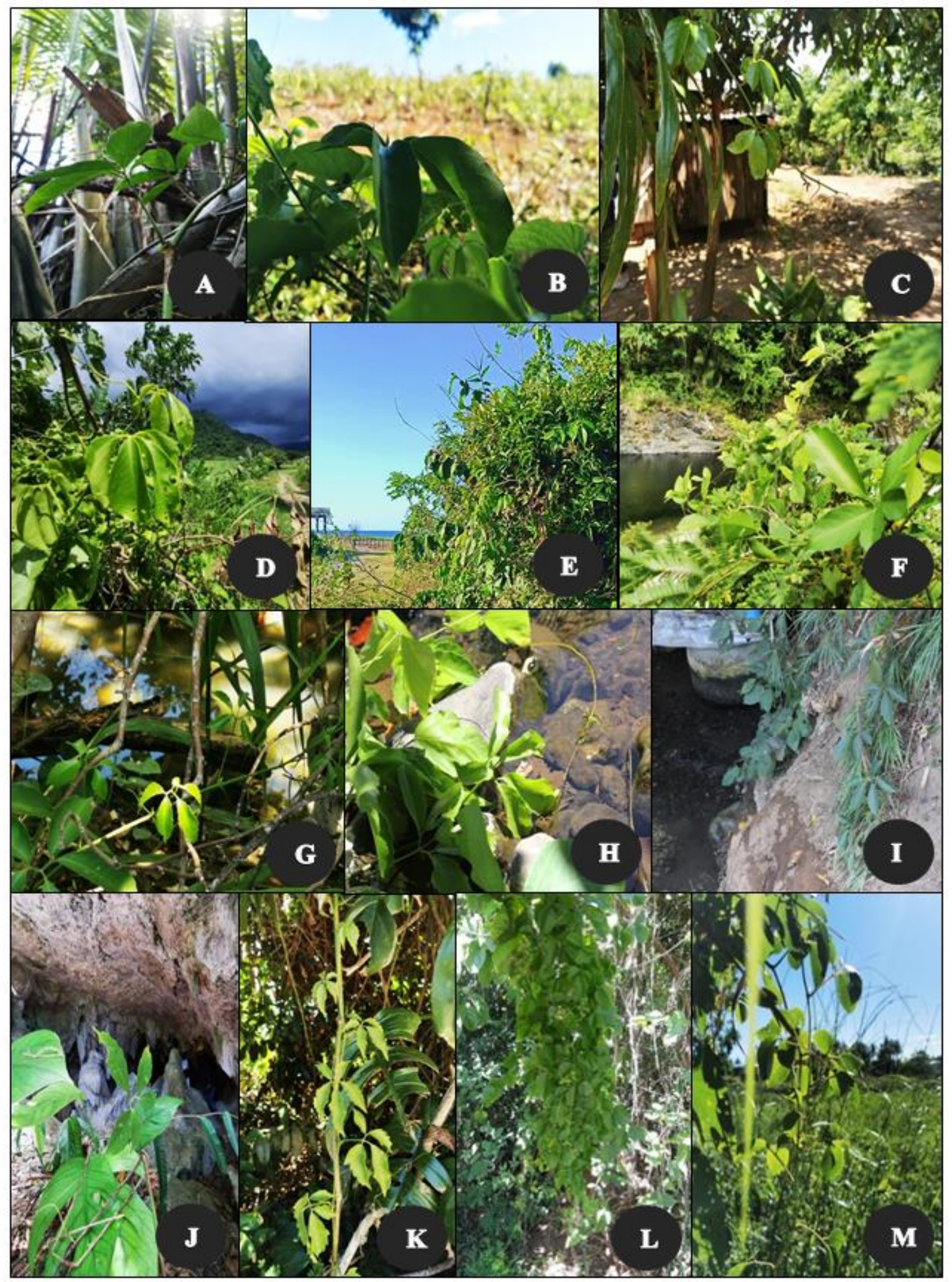

Figure 3. Tetrastigma harmandii Planch. and Cayratia trifolia (Linn.) Domin. growing in various habitats in northeastern Cagayan, Luzon, Philippines. T. harmandii growing in A. nipa plantation , B. agricultural land, C. residential area, D. grassland, E. near coastal area, F. dam, G. creek, H. river, I. spring, J. outside the cave, and K. secondary growth forest; C. trifolia growing in L. secondary growth forest and M. swampy area. 
Table 2. Growing environment of Cayratia trifolia and Tetrastigma harmandii in northeastern Cagayan, Luzon, Philippines

\begin{tabular}{|c|c|c|c|c|c|}
\hline Species & $\begin{array}{l}\text { Collec- } \\
\text { tion Site }\end{array}$ & $\begin{array}{c}\text { Elevation } \\
\text { (m asl) }\end{array}$ & Habitat & $\begin{array}{c}\text { Soil chemical } \\
\text { properties }\end{array}$ & $\begin{array}{l}\text { Native/endemic plants growing within the environ- } \\
\text { ment }\end{array}$ \\
\hline $\begin{array}{l}\text { C. trifo- } \\
\text { lia }\end{array}$ & $\begin{array}{l}\text { Lal-lo, } \\
\text { Sta. Tere- } \\
\text { sita }\end{array}$ & $\begin{array}{l}53.04- \\
78.03\end{array}$ & $\begin{array}{l}\text { lowland, } \\
\text { near a } \\
\text { swamp, } \\
\text { hills, } \\
\text { secondary } \\
\text { growth } \\
\text { forests/ } \\
\text { open for- } \\
\text { ests }\end{array}$ & $\begin{array}{l}\text { pH: 6.78-7.27 } \\
\pm 0.61, \\
\text { OM (\%): } 2.79- \\
3.51 \pm 0.22 \\
\text { P (ppm): } 12.70- \\
14.90 \pm 0.64 \\
\text { K (ppm): } 117.0- \\
258.0 \pm 40.78 \\
\text { Cu (ppm): } 0.88- \\
1.62 \pm 0.22 \\
\text { Zn (ppm): } 0.98- \\
1.68 \pm 0.20 \\
\text { Fe (ppm): } 3.20- \\
9.60 \pm 1.86, \\
\text { Mn (ppm): } 3.80- \\
18.0 \pm 4.10\end{array}$ & $\begin{array}{l}\text { Leucaena leucocephala (Lam.) de Wit [Lead tree/ Ipil- } \\
\text { ipil] } \\
\text { Gliciridia sepium (Jacq.) Kunth ex Walp. [St. Vincent } \\
\text { Plum/Kakawate] } \\
\text { Swietenia mahogani (L.) Jacq. [Mahogany] }\end{array}$ \\
\hline $\begin{array}{l}\text { T. har- } \\
\text { mandii }\end{array}$ & $\begin{array}{l}\text { Lal-lo, } \\
\text { Aparri, } \\
\text { Camala- } \\
\text { niugan } \\
\text { Buguey, } \\
\text { Sta. } \\
\text { Teresita, } \\
\text { Gonzaga, } \\
\text { Sta. Ana, } \\
\text { Palaui Is- } \\
\text { land }\end{array}$ & $\begin{array}{l}18.90- \\
181.97\end{array}$ & $\begin{array}{l}\text { lowland, } \\
\text { hills, } \\
\text { residential } \\
\text { areas, } \\
\text { near } \\
\text { coastal ar- } \\
\text { eas (ap- } \\
\text { prox. 5- } \\
\text { 200 meters } \\
\text { from the } \\
\text { sea), } \\
\text { nipa plan- } \\
\text { tations, } \\
\text { agricul- } \\
\text { tural lands, } \\
\text { grasslands, } \\
\text { near rivers, } \\
\text { creeks, } \\
\text { dam, } \\
\text { swamp, } \\
\text { spring, and } \\
\text { irrigation } \\
\text { canals, } \\
\text { outside the } \\
\text { caves, } \\
\text { secondary } \\
\text { growth } \\
\text { forests / } \\
\text { open for- } \\
\text { ests } \\
\text { Palaui Is- } \\
\text { land coast- } \\
\text { line }\end{array}$ & $\begin{array}{l}\text { pH: 5.25-6.71 } \\
\pm 0.43, \\
\text { OM (\%): } \\
0.41-3.99 \pm 1.06 \\
\text { P (ppm): } 20.80- \\
100.0 \pm 25.67 \\
\text { K (ppm): } 296.0- \\
707.0 \pm 128.69 \\
\mathrm{Cu}(\mathrm{ppm}): 0.28- \\
2.28 \pm 0.28 \\
\mathrm{Zn}(\mathrm{ppm}): 0.48- \\
1.38 \pm 0.62 \\
\text { Fe (ppm): } \\
26.60 \pm 9.57 \\
\mathrm{Mn}(\mathrm{ppm}): 5.20- \\
37.60 \pm 5.37\end{array}$ & 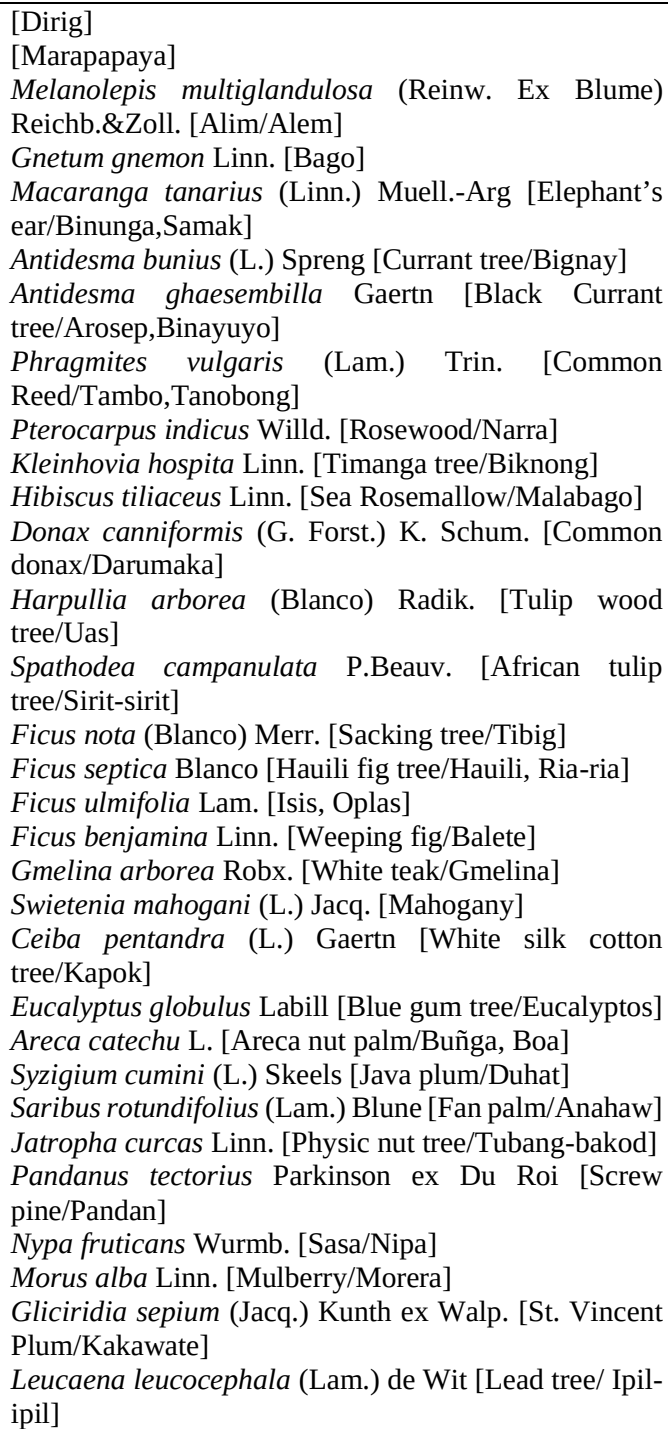 \\
\hline
\end{tabular}

Remarks: *pH: Potentiometric; N: Walkey \& Black Spectrophotometric; P: Olsen; K: Cold Sulfuric Extraction; Cu, Zn, Fe, Mn: diethylenetriaminepentaacetic acid (DTPA)

$\mathrm{n}=5$, mean \pm Std. Error.

Observations were done on June-October 2020.

Names inside brackets [ ] are common names of plant species. 
found creeping on the ground but most of the vines were climbing on plant species such as Ipil-ipil [Leucaena leucocephala (Lam.) de Wit] and Kakawate [Gliciridia sepium (Jacq.) Kunth ex Walp.]. Native/endemic trees such as Alem [Melanolepis multiglandulosa (Reinw. Ex Blume) Reichb. \& Zoll.], Bago [Gnetum gnemon Linn.], Samak [Macaranga tanarius (Linn.) Muell.-Arg], Bignay [Antidesma bunius (L.) Spreng], Binayuyo [Antidesma ghaesembilla Gaertn], Tanobong [Phragmites vulgaris (Lam.) Trin.], Narra [Pterocarpus indicus Willd.], Biknong [Kleinhovia hospita Linn.], Malabago [Hibiscus tiliaceus Linn.], Darumaka [Donax canniformis (G. Forst.) K. Schum.], Uas [Harpullia arborea (Blanco) Radik.], Tibig [Ficus nota (Blanco) Merr.], Ria-ria [Ficus septica Blanco], Oplas [Ficus ulmifolia Lam.], and other species also grew within the $T$. harmandii environment (Table 2).

Concerning soil growing conditions, C. trifolia grew in soils with slightly acidic to moderately alkaline $\mathrm{pH}$, medium to high organic matter content, medium amount of phosphorus, and low to high potassium content. Furthermore, the soils contained a high amount of copper, low to medium zinc, low to high iron, and a high to very high amount of manganese. On the other hand, T. harmandii grew in soils with strongly acidic to slightly acidic $\mathrm{pH}$, low to medium organic matter content, high to excessive phosphorus content, and high potassium content. In addition, the soils also had low to high copper, very low to medium zinc, and high to very high iron and manganese contents (Table 2). Both species can grow in marginal soils with acidic conditions and low nutrient content. $C$. trifolia grew in soils with low potassium, low zinc, and iron contents while T. harmandii grew in soils with low organic matter and low micronutrients such as copper and zinc.

Comparing the soil properties where $C$. trifolia and $T$. harmandii thrived, the former species grew in soils with higher $\mathrm{pH}$ (0.56-1.53 higher) as compared to the latter species which grew in soils with a lower $\mathrm{pH}$ (0.56-1.53 lower). T. harmandii grew in soils with lower organic matter $(0.48-2.38 \%$ lower), higher phosphorus (8.10-85.10 ppm higher), higher potassium (179.0-449.0 ppm higher), lower zinc, (0.30-0.50 ppm lower), and higher copper (0.66 ppm higher), iron (4.40-16.60 ppm higher), and manganese (1.40-19.60 ppm higher) contents as compared to $C$. trifolia which grew in soils with lower macronutrients and micronutrient levels.

\section{Phytochemical properties of the medicinal Vita- ceae species}

Phytochemical screening of plants posts an important role in identifying new sources of therapeutically, nutritionally, and industrially important compounds or chemicals. To compare the two medicinal Vitaceae species, their phytochemical profiles were examined (Table 3). C. trifolia leaves contained almost all the secondary metabolites tested namely alkaloids, flavonoids, phenols, terpenoids, anthocyanins, tannins, and saponins except steroids while the $T$. harmandii leaves only contained phenols, terpenoids, tannins, and saponins. Steroid was not present in the two medicinal Vitaceae species. The presence of saponins, alkaloids, flavonoids, and tannins in C. trifolia [22] and saponins in T. harmandii [23] plant extracts were also reported in other studies. Medicinal plants were reported to contain some natural products or bioactive substances such as tannins, alkaloids, terpenoids, steroids, flavonoids, [24], phenolic compounds [25], and saponins [26].

\section{Antibacterial properties of the medicinal Vita- ceae species}

To compare the two medicinal Vitaceae species, their antibacterial activities were examined (Table 4). When tested against Staphylococcus aureus, a gram-positive bacterial strain, C. trifolia and T. harmandii exhibited antibacterial activity with $12 \mathrm{~mm}$ and $10 \mathrm{~mm}$ mean zones of inhibition, respectively. The two medicinal Vitaceae species showed a partially active reaction against the said pathogenic bacterial strain. The antibacterial activity of $C$. trifolia n-hexane plant extract against $S$. aureus was also reported [27]. Furthermore, $T$. harmandii leaf extract demonstrated a least active reaction against Klebsiella aerogenes with a $9 \mathrm{~mm}$ mean zone of inhibition. Based on the phytochemical screening, the species contain secondary metabolites such as flavonoids and terpenoids which are known to have antibacterial activities [28, 29]. Moreover, both species contain tannins and saponins which were reported to demonstrate an antibacterial action against $S$. aureus [30, 31, 32]. $S$. aureus infection is a major cause of diseases such as bacteremia, skin and soft tissue infections, endocarditis, metastatic infections, sepsis, and toxic 
Table 3. Phytochemical screening of Cayratia trifolia and Tetrastigma harmandii ethanolic leaf extracts

\begin{tabular}{cccc}
\hline Secondary Metabolites & Test Method & C. trifolia & T. harmandii \\
\hline Alkaloids & Mayer’s Test & Present & Absent \\
Anthocyanin & NaOH Test & Present & Absent \\
Flavonoids & Shinoda Test & Present & Absent \\
Phenols & Ferric Chloride Test & Present & Present \\
Saponins & Froth Test & Present & Present \\
Steroids & Liebermann-Buchard Reaction & Absent & Absent \\
Tannins & Lead Acetate Test & Present & Present \\
Terpenoids & Salkowski Test & Present & Present \\
\hline
\end{tabular}

Table 4. Antibacterial activity of Cayratia trifolia and Tetrastigma harmandii ethanolic leaf extracts

\begin{tabular}{lcccc}
\hline \multirow{2}{*}{ Bacteria } & \multicolumn{2}{c}{ C. trifolia } & \multicolumn{2}{c}{ T. harmandii } \\
\cline { 2 - 5 } & Zone of Inhibition $(\mathrm{mm})^{*}$ & Activity & Zone of Inhibition (mm)* & Activity \\
\hline Staphylococcus aureus & 12.0 & + & 10.0 & + \\
Escherichia coli & 6.0 & - & 6.0 & - \\
Pseudomonas aeruginosa & 6.0 & - & 6.0 & - \\
Enterococcus faecium & 6.0 & - & 6.0 & - \\
Klebsiella pneumonia & 6.0 & - & 6.0 & - \\
Klebsiella aerogenes & 6.0 & - & 9.0 & $+/-$ \\
Acinetobacter baumannii & 6.0 & - & 6.0 & - \\
\hline
\end{tabular}

Remarks: Control (distilled water) - $6.0 \mathrm{~mm}$

$\mathrm{n}=3,(+)$ inhibited, $(-)$ uninhibited

$*(<10 \mathrm{~mm})$ maybe expressed as inactive, $(10-13 \mathrm{~mm})$ partially active, $(14-19 \mathrm{~mm})$ active, $(>19 \mathrm{~mm})$ very active

shock syndrome [33]. Thus, the two medicinal Vitaceae species have potential in the treatment of these diseases.

\section{Conclusion}

C. trifolia and T. harmandii were both found growing in northeastern Cagayan. T. harmandii grew in a wide range of habitats, from lower to higher elevations, and soils with higher nutrients while $C$. trifolia only grew in some habitats with mid-elevations and soils with higher $\mathrm{pH}$. Both species grew in environments where ipil-ipil (Leucaena leucocephala) and kakawate (Gliciridia sepium) trees were found. Furthermore, C. trifolia ethanolic leaf extract contains more secondary metabolites as compared to T. harmandii. Both species can inhibit the activity of $S$. aureus while a slight inhibiting activity against $K$. aerogenes was observed in the ethanolic leaf extracts of $T$. harmandii.

With our findings, the potential of utilizing the species in product development for medicinal, therapeutic, and industrial purposes is an opportunity. The present findings on the habitat conditions of the two medicinal Vitaceae species will guide future researchers in investigating their growing environments in other places, localities, or ecosystems. Moreover, the concentrations in various plant parts and the specific identities of the phytochemicals present in the two Vitaceae species should be further explored. Initial findings on the antibacterial potential of C. trifolia and T. harmandii against $S$. aureus will guide future researchers in evaluating the efficacy of medicinal Vitaceae plant extracts in treating various diseases caused by the pathogenic bacteria.

\section{Acknowledgement}

This study was funded by the Cagayan State University (CSU) through the leadership of the University President Dr. Urdujah G. Alvarado and was supported by the Cagayan State UniversityGonzaga Campus (CSU-G) through its Campus Executive Officer, Dr. Froilan A. Pacris, Jr., CSUG Project Ariwat/Ayo Team (Dr. Calixto B. Alicay, Charlot L. Maramag, Gerlie U. Bayani, Marvin V. Baloloy, Lyle B. Sumer, Dr. Claribel A. Gaspar, and Jean S. Torres); Municipal Environment and Natural Resources Offices (MENROs) of northeastern Cagayan municipalities; Department of Environment and Natural Resources Protected Area Management Board of Palaui Island (DENR-PAMB); Coast Guard Station Aparri; Coast Guard Sub-Station Santa Ana, Cagayan; CSU Lal-lo Campus; Central Analytical Laboratory of the CSU-Andrews Campus; and the 
Regional Soils Laboratory of the Cagayan Valley Integrated Agricultural Laboratory, Department of Agriculture Region 2,

Tuguegarao City, Cagayan.

\section{References}

1. Garden CA, Bennet HW (1956) The Toxic Plant of Western Australian Path. The West Australian News Paper.

2. Pelser PB, Nickrent DL, Barcelona JF (2016) Untangling a vine and its parasite: Host specificity of Philippine Rafflesia (Rafflesiaceae). Taxon 65(4): 739-758. doi: 10.12705/654.4.

3. Pranata S, Sulistijorini S, Chikmawati T. (2019) Ecology of Rafflesia arnoldii (Rafflesiaceae) in Pandam Gadang West Sumatra. Journal of Tropical Life Science 9(3): 243-252. doi: 10.11594/jtls.09.03.05.

4. Anita Jasuja ND, Mathur M (2019) Evaluation of Primary Metabolites and Antioxidant Potential Activity of Cayratia trifolia (Leaf and Stems). Journal of Drug Delivery and Therapeutics 9(4-A):367-372. doi: 10.22270/jddt.v9i4-A.3492.

5. Kumar D, Gupta J, Kumar S et al. (2012) Pharmacognostic evaluation of Cayratia trifolia (Linn.) leaf. Asian Pacific Journal of Tropical Biomedicine 2(1): 6-10. doi: 10.1016/S2221-1691(11)60180-9.

6. Arora J, Roat C, Goyal S, Ramawat KG (2009) High Stilbenes accumulation in root culture of Cayratia trifolia (L.) Domin grown in shake flask. Acta Physiologiae Plantarum 31: 1307-11. doi: 10.1007/s11738-009-03593.

7. Chellaperumal P, Sophia D, Arulraj C et al. (2012) In vitro antioxidant activities and HPTLC analysis of ethanolic extract of Cayratia trifolia (L.). Asian Pacific Journal of Tropical Disease 952-956. doi: 10.1016/S22221808(12)60299-0.

8. Gupta J, Kumar D, Gupta A (2012) Evaluation of gastric anti-ulcer activity of methanolic extract of Cayratia trifolia in experimental animals. Asian Pacific Journal of Tropical Disease 2(2): 99-102. doi: 10.1016/S22221808(12)60024-3.

9. Kumar DG, Vattachanakkal MS, Rathi MA et al. (2011) Hepatoprotective activity of Cayratia trifolia (L.) Domin against nitrobenzene induced hepatotoxicity. Latin American Journal of Pharmacy 30(3): 546-9.

10. Santoso D, Sudiana IK, Rahayu AS, Yunus M (2019) Anti-inflammatory effect of ethyl acetate fraction of galing plant extract (Cayratia trifolia) on male wistar rats induced by carrageenan. In Journal of Physics: Conference Series (Vol. 1146, No. 1, p. 012021). IOP Publishing. doi: 10.1088/1742-6596/1146/1/012021.

11. Arora J, Joshi A, Kanthaliya B, Khan F (2020) Effect of biotic elicitors on polyphenol production in Cayratia trifolia cell suspension cultures analyzed by HPLC. BioTechnologia 101(1): 35-43. doi: 10.5114/bta.2020.92926.

12. Batra S, Batra N, Nagori BP (2013) Preliminary phytochemical studies and evaluation of antidiabetic activity of roots of Cayratia trifolia (L.) Domin in alloxan induced diabetic albino rats. Journal of Applied Pharmaceutical Science 3(3), 97-100. doi: 10.7324/JAPS.2013.30319

13. Yusuf MI, Susanty S, Fawwaz M (2018) Antioxidant and antidiabetic potential of galing stem extract (Cayratia trifolia Domin). Pharmacognosy Journal 10(4): 686-689. doi: 10.5530/pj.2018.4.113.

14. Chungsamarnyart N, Sirinarumitr T, Chumsing W, Wajjawalku W (2007) In vitro study of antiviral activity of plant crude-extracts against the foot and mouth disease virus. Agriculture and Natural Resources 41(5): 97-103.

15. Rahmatullah M, Mollik MAH, Islam MK et al. (2010) A survey of medicinal and functional food plants used by the folk medicinal practitioners of three villages in Sreepur Upazilla, Magura district, Bangladesh. American Eurasian Journal of Sustainable Agriculture 4(3): 363373.

16. Quisumbing E (1951) Medicinal plants of the Philippines. Manila (Philippines): Bureau of Printing.

17. Brown WH (1920) Minor products of Philippine forests Vol. 1, No.3. Department of Agriculture and Natural Resources, Bureau of Forestry Bulletin No. 22, Volume 3, Manila, Philippines. 329p. https://quod.lib.umich.edu/p/philamer/ADR0460.0001.0 03?rgn=main;view=fulltext. Accessed date: December 2020.

18. Motsara MR, Roy RN (2008) Guide to laboratory establishment for plant nutrient analysis. Rome, Italy. Food and Agriculture Organization of the United Nations.

19. Horneck DA, Sullivan DM, Owen JS, Hart JM (2011) Soil test interpretation guide. Oregon State University Extension Service, Corvallis, USA, 12 pp. https://ir.library.oregonstate.edu/downloads/00000020g. Accessed date: December 2020.

20. Pelser PB, Barcelona JF, Nickrent DL (2011) Vitaceae: Co's Digital Flora of the Philippines. https://www.philippineplants.org/Families/Vita-

ceae.html?fbclid=IwAR0HTwRjTONNMRPGsbQvIuhGed0LMQBqMP5WZxt_qiLq3WTjtHMeMzIw7ok. Accessed date: November 2020.

21. Guevarra BQ (2005) A Guidebook to Plant Screening: Phytochemical and Biological. España, Manila, Philippines. UST Publishing House.

22. Perumal PC, Sophia D, Raj CA et al. (2012) In vitro antioxidant activities and HPTLC analysis of ethanolic extract of Cayratia trifolia (L.). Asian Pacific Journal of tropical disease 2, S952-S956. doi: 10.1016/S22221808(12)60299-0.

23. Antonio MA, Buot Jr IE (2019) Refining the concept of weeds. J. Wetlands Biodiversity 9: 7-21.

24. Edeoga HO, Okwu DE, Mbaebie BO (2005) Phytochemical constituents of some Nigerian medicinal plants. African Journal of Biotechnology 4(7): 685-688. doi: 10.5897/AJB2005.000-3127.

25. Singh R, Singh S, Kumar S, Arora S (2007) Evaluation of antioxidant potential of ethyl acetate extract/fractions of Acacia auriculiformis A. Cunn. Food and Chemical Toxicology 45(7): 1216-1223. doi: 10.1016/j.fct.2007.01.002.

26. Shi J, Arunasalam K, Yeung D et al. (2004) Saponins from edible legumes: chemistry, processing, and health benefits. Journal of Medicinal Food 7(1): 67-78. doi: 10.1089/109662004322984734.

27. Meganathan B, Palanisamy CP, Panagal M (2021) Antioxidant, antimicrobial and cytotoxicity potential of nhexane extract of Cayratia trifolia L. Bioinformation 17(3): 452-459. doi: 10.6026/97320630017452.

28. Cushnie TT, Lamb AJ (2005) Antimicrobial activity of flavonoids. International Journal of Antimicrobial 
Agents 26 (5): 343-356. doi: 10.1016/j.ijantimicag.2005.09.002.

29. Popova MP, Chinou IB, Marekov IN, Bankova VS (2009) Terpenes with antimicrobial activity from Cretan propolis. Phytochemistry 70(10): 1262-1271. doi: 10.1016/j.phytochem.2009.07.025.

30. Akiyama H, Fujii K, Yamasaki O et al. (2001) Antibacterial action of several tannins against Staphylococcus aureus. Journal of Antimicrobial Chemotherapy 48 (4): 487-491. doi: 10.1093/jac/48.4.487.

31. Avato P, Bucci R, Tava A et al. (2006) Antimicrobial activity of saponins from Medicago sp.: structure- activity relationship. Phytotherapy Research 20(6): 454457. doi: 10.1002/ptr.1876.

32. Khan MI, Ahhmed A, Shin JH et al. (2018) Green tea seed isolated saponins exerts antibacterial effects against various strains of gram positive and gram negative bacteria, a comprehensive study in vitro and in vivo. EvidenceBased Complementary and Alternative Medicine 2018: 112. doi: 10.1155/2018/3486106.

33. Lowy FD (1998) Staphylococcus aureus infections. New England Journal of Medicine 339(8): 520-532. doi: 10.1056/NEJM199808203390806. 
This page is intentionally left blank. 